\title{
PRISPEVEK ŠOL K OKOLJSKEMU RAZVOJU LOKALNIH SKUPNOSTI
}

\author{
Ana Vovk Korže \\ Univerza v Mariboru, Filozofska fakulteta, Koroška c. 160, \\ SI- 2000 Maribor, Slovenija. \\ e-mail: ana.vovk@uni-mb.si
}

Strokovni članek

COBISS 1.04

\section{Izvleček}

V prispevku je predstavljeno sodelovanje šol pri okoljskem razvoju občin kot posledica projekta EUBIS. V ta namen smo z izbranimi šolami vodili izdelavo učne pot v občini Radlje ob Dravi, izdelali priročnik za medpredmetno okoljsko vzgojo s šolo v Murski Soboti in vključili OŠ Muta v pripravo evropskih projektov, na način, da je šola stalni partner dogodkov, ki se ob izvajanju teh projektov dogajajo. S tem smo uspeli potrditi tezo, da imajo šole velik potencial, ki je premalo izkoriščen v lokalnem okolju.

Ključne besede: okoljski razvoj, izobraževanje, aktivna participacija, trajnostni razvoj

\section{SCHOOL CONTRIBUTION TO THE ECOLOGICAL DEVELOPMENT THE LOCAL COMUNITIES}

\begin{abstract}
The schools' cooperation at environmental development of communes is presented in our contribution as the result of the EUBIS project. With this goal in mind the selected schools were involved in preparation of the teaching path in the Radlje ob Dravi community, in elaboration of the handbook for intersubject environmental education in municipality Murska Sobota and also in the preparation of european projects in Muta community, where the school is permanent partner in all events, which are parts of those projects. We believe, that we have confirmed the hypothesis, that the schools have large potencial, which should be more used in the local society.
\end{abstract}

Key words: environmental development, education, active partizipation, sustainable development 


\section{UVOD}

Z vstopom Slovenije v Evropsko unijo se je naša država zavezala, da bo z državami Evrope še tesneje sodelovala tudi na področju izobraževanja (Lisbonska deklaracija). Tako je Slovenija pristopila tudi k sodelovanju v projektu EUBIS (EU - državljanstvo: Družbena partizipacija za Evropo se začne v šoli). Glavni cilj tega projekta je, da bi »okrepili procese participacije v šoli in družbi tako, da se bodo razvili učenci v aktivne in odgovorne državljane v družbi« (EUBIS, zloženka izdana ob predstavitvi projekta, Socrates, Education and Culture). Slovenijo v tem projektu zastopa Univerza v Mariboru, Filozofska fakulteta. K sodelovanju so bile povabljene tri izbrane osnovne šole, in sicer OŠ Murska Sobota, OŠ Muta ter OŠ Radlje ob Dravi. Vse tri OŠ so tesno povezane z dogajanjem preko naših meja. OŠ Muta in Radlje ob Dravi se zaradi bližine avstrijske meje in tradicije močno povezuje z sosednjo Avstrijo, OŠ Murska Sobota pa je močno povezana z tradicijo Prekmurja ter sosednjo Madžarsko. Vodstva vseh treh šol so v projekt vključila učence 8. in 9. razredov, starih od 13 do 15 let. Le ti so izpolnili že v naprej pripravljene anketne vprašalnike, in tako pripomogli pridobit pomembne podatke iz področja sodelovanja učencev $\mathrm{v}$ javnem življenju.

\section{Cilji projekta EUBIS:}

Projekt doprinaša k razvoju današnjih študirajočih, da postanejo bolj odgovorni in kritični državljani, da razvijejo sposobnost participacije in zahtevane kompetence. Glavni cilj projekta je okrepiti procese participacije v šoli in družbi, da bodo s tem bodo postajali učenci bolj odgovorni državljani in prispevali h skupni rasti Evrope.

Podcilji projekta pa so:

- $\quad$ vzpodbujati mlade, da postanejo aktivni pri pouku in v družbi,

- doprinesti h razvoju pouka in učnih kultur v smislu širitve pojma demokracija

- omogočati mladim participacijo v šoli in v družbi

- napravi participacijo pri pouku transparetno, reflektivno in preverljivo

- razviti interaktivne metode in strategije med šolo in družbo

- omogočiti učiteljem, da razvijejo kot nujno kompetenco participacijo v družbi

- omogočiti učiteljem, da obvladajo oblike in poti participacije pri mladih pri pouku.

\section{Glavne aktivnosti:}

- analiza učnih načrtov, obstoječih materialov, primerov dobrih praks

- preizkušnja in evalvacija na nacionalni in transparentni ravni

- razširitev in valorizacija rezultatov na nacionalni in evropski ravni

- razvoj in izvedba Comenius seminarjev.

\section{Rezultati:}

- moduli za izobraževanje učiteljev

- brošure, načrti Eubis z rezultati na CD romu

- „Civilni-Portfolio“

- letak Partizipacija mladih “ 


\section{Ciljne skupine:}

Učitelji comenis- seminarjev, učenci, udeleženci izobraževanj, občine, skupnosti in drugi.

Na izbranih treh šolah smo opravili anketiranje učencev in sicer smo v vsaki šoli razdelili 93 anketnih listov. Učenci so z zanimanjem izpolni vprašalnike. Temu je sledila analiza anketnih vprašalnikov. Med vsemi anketnimi vprašanji smo izpostavili 10 vprašanj, ki se najtesneje navezujejo na sodelovanje učencev $\mathrm{z}$ šolo, zunanjim svetom in sodelovanje pri pouku. Pomembna je bila podpora šole, ki je projekt zelo vestno vključila v svoj sestavni del življenja na šoli.

\section{REZULTATI OPRAVLJENIH ANKETNIH VPRAŠALNIKOV}

\section{OŠ Murska Sobota}

Preglednica 1: Vključenost $v$ šolsko življenje.

Table 1: Included in school life

\begin{tabular}{|l|c|c|c|c|}
\hline Ali imaš možnosti v tvoji šoli sodelovati na naslednjih področjih? & Ja & Prej ja & Prej ne & Ne \\
\hline \multirow{2}{*}{ Šolski Parlament. (92) } & 46 & 18 & 4 & 24 \\
& $50,0 \%$ & $19,6 \%$ & $4,3 \%$ & $26,1 \%$ \\
\hline
\end{tabular}

Preglednica 2: Mnenje k izjavam

Table 2: Opinien of statements

\begin{tabular}{|l|c|c|c|c|}
\hline Kaj meniš k naslednjim izjavam? & Ja & Prej ja & Prej ne & Ne \\
\hline Na moji šoli želim več sodelovati. (90) & 33 & 19 & 14 & 24 \\
& $36,7 \%$ & $21,1 \%$ & $15,6 \%$ & $26,7 \%$ \\
\hline $\begin{array}{l}\text { Preko predstavnika šole lahko aktivno sodelujem pri organizaciji } \\
\text { življenja na šoli. (91) }\end{array}$ & 23 & 16 & 17 & 35 \\
\hline
\end{tabular}

Preglednica 3: Sodelovanje pri pouku

Table 3: Partizipation in the classroom

\begin{tabular}{|l|c|c|c|c|}
\hline & Ja & Prej ja & Prej ne & Ne \\
\hline Lahko sooblikujemo pouk. (92) & 30 & 13 & 20 & 29 \\
& $32,6 \%$ & $14,1 \%$ & $21,7 \%$ & $31,5 \%$ \\
\hline Učitelji upoštevajo naše mnenje. (92) & 34 & 22 & 20 & 16 \\
\hline Menim, da se pouk ne sme dogajati samo v razredu, ampak tudi & $37,0 \%$ & $23,9 \%$ & $21,7 \%$ & $17,4 \%$ \\
izven. (93) & $74,2 \%$ & 9 & 3 & 12 \\
\hline
\end{tabular}

Na OŠ Murska Sobota poznajo šolski parlament, toda preko predstavnikov šole učenci le delno sodelujejo. Tudi sicer otroci niso izrazili prevelikega interesa po aktivnem sodelovanju v šoli, čeprav imajo možnosti, da sooblikujejo pouk in učitelji upoštevajo njihovo mnenje. Večina učencev pa meni, da mora pouk potekati tudi izven razreda. $V$ družbenem življenju 
so otroci manj aktivni, ne zanimajo se za dogajanja v lastni občini, nekoliko bolj s zanimajo za dogajanja v lastni državi, o političnih dogodkih pa se skoraj ne pogovarjajo.

Preglednica 4: Sodelovanje v družbenem življenju

Table 4: Partizipation in social life

\begin{tabular}{|l|c|c|c|c|}
\hline & Ja & Prej ja & Prej ne & Ne \\
\hline Zanimam se, kaj se dogaja v moji občini. (91) & 15 & 12 & 16 & 48 \\
& $16,5 \%$ & $13,2 \%$ & $17,6 \%$ & $52,7 \%$ \\
\hline \multirow{2}{*}{ Zanimam se, kaj se dogaja v moji državi. (92) } & 36 & 23 & 9 & 24 \\
& $39,1 \%$ & $25,0 \%$ & $9,8 \%$ & $26,1 \%$ \\
\hline \multirow{2}{*}{ Zanimam se, kaj se dogaja v Evropi. (92) } & 28 & 24 & 13 & 27 \\
\hline \multirow{2}{*}{ Pri pouku se pogovarjamo o političnih dogajanjih. (92) } & $30,4 \%$ & $26,1 \%$ & $14,1 \%$ & $29,3 \%$ \\
\hline
\end{tabular}

\section{Ǒs Muta:}

Preglednica 5: Vključenost $v$ šolsko življenje

Table 5: Included in school life

\begin{tabular}{|l|c|c|c|c|}
\hline Ali imaš možnosti v tvoji šoli sodelovati na naslednjih področjih? & Ja & Prej ja & Prej ne & $\mathrm{Ne}$ \\
\hline \multirow{2}{*}{ Šlski Parlament. (87) } & 25 & 15 & 12 & 35 \\
& $28,7 \%$ & $17,2 \%$ & $13,8 \%$ & $40,2 \%$ \\
\hline
\end{tabular}

\section{Preglednica 6: Mnenje k izjavam}

Table 6: Opinien of statements

\begin{tabular}{|l|c|c|c|c|}
\hline Kaj meniš h naslednjim izjavam? & Ja & Prej ja & Prej ne & Ne \\
\hline Na moji šoli želim več sodelovati. (88) & 31 & 22 & 18 & 17 \\
& $35,2 \%$ & $25,0 \%$ & $20,5 \%$ & $19,3 \%$ \\
\hline Preko predstavnika šole lahko aktivno sodelujem pri organizaciji & 19 & 12 & 20 & 36 \\
življenja na šoli. (87) & $21,8 \%$ & $13,8 \%$ & $23,0 \%$ & $41,4 \%$ \\
\hline
\end{tabular}

\section{Preglednica 7: Sodelovanje pri pouku}

Table 7: Partizipation in the classroom

\begin{tabular}{|l|c|c|c|c|}
\hline & Ja & Prej ja & Prej ne & Ne \\
\hline & 18 & 22 & 15 & 32 \\
Lahko sooblikujemo pouk. (87) & $20,7 \%$ & $25,3 \%$ & $17,2 \%$ & $36,8 \%$ \\
\hline & 23 & 37 & 19 & 9 \\
Učitelji upoštevajo naše mnenje. (88) & $26,1 \%$ & $42,0 \%$ & $21,6 \%$ & $10,2 \%$ \\
\hline Menim, da se pouk ne sme dogajati samo v razredu, ampak tudi & 68 & 14 & 2 & 5 \\
izven. (89) & $76,4 \%$ & $15,7 \%$ & $2,2 \%$ & $5,6 \%$ \\
\hline
\end{tabular}


Preglednica 8: Sodelovanje v družbenem življenju

Table 8: Partizipation in social life

\begin{tabular}{|l|c|c|c|c|}
\hline & Ja & Prej ja & Prej ne & Ne \\
\hline Zanimam se, kaj se dogaja v moji občini. (88) & 19 & 22 & 20 & 27 \\
& $21,6 \%$ & $25,0 \%$ & $22,7 \%$ & $30,7 \%$ \\
\hline Zanimam se, kaj se dogaja v moji državi. (89) & 20 & 30 & 18 & 21 \\
& $22,5 \%$ & $33,7 \%$ & $20,2 \%$ & $23,6 \%$ \\
\hline Zanimam se, kaj se dogaja v Evropi. (87) & 28 & 23 & 20 & 16 \\
& $32,2 \%$ & $26,4 \%$ & $23,0 \%$ & $18,4 \%$ \\
\hline Pri pouku se pogovarjamo o političnih dogajanjih. (89) & 6 & 24 & 25 & 34 \\
& $6,7 \%$ & $27,0 \%$ & $28,1 \%$ & $38,2 \%$ \\
\hline
\end{tabular}

$\mathrm{Na}$ OŠ Muta slabo poznajo šolski parlament, želijo pa aktivno sodelovati, v šolsko življenje so preko predstavnikov šol vključeni bolj slabo. Pogrešajo možnosti sooblikovanja pouka, ocenjujejo, da učitelji upoštevajo njihovo mnenje in večinsko podpirajo izjavo, da se mora pouk dogajati tudi izven razreda. Aktivnost učencev OŠ Muta v družbenem življenju je slabša, saj se večinoma ne zanimajo za dogajanja v občni, udi ne v lastni državi in nekaj več v Evropi, o političnih dogodkih se redkeje pogovarjajo.

\section{OŠ Radlje ob Dravi:}

Preglednica 9: Vključenost v šolsko življenje

Table 9: Included in school life

\begin{tabular}{|l|c|c|c|c|}
\hline Ali imaš možnosti v tvoji šoli sodelovati na naslednjih področjih? & Ja & Prej ja & Prej ne & Ne \\
\hline Šolski Parlament. (91) & 23 & 16 & 4 & 48 \\
& $25,3 \%$ & $17,6 \%$ & $4,4 \%$ & $52,7 \%$ \\
\hline
\end{tabular}

\section{Preglednica 10: Mnenje k izjavam}

Table 10: Opinien of statements

\begin{tabular}{|l|c|c|c|c|}
\hline Kaj meniš h naslednjim izjavam? & Ja & Prej ja & Prej ne & Ne \\
\hline Na moji šoli želim več sodelovati. (92) & 42 & 15 & 12 & 23 \\
& $45,6 \%$ & $16,3 \%$ & $13,0 \%$ & $25,0 \%$ \\
\hline $\begin{array}{l}\text { Preko predstavnika šole lahko aktivno sodelujem pri organizaciji } \\
\text { življenja na šoli. (91) }\end{array}$ & 21 & 15 & 19 & 36 \\
\end{tabular}

\section{Preglednica 11: Sodelovanje pri pouku}

Table 11: Partizipation in the classroom

\begin{tabular}{|l|c|c|c|c|}
\hline & Ja & Prej ja & Prej ne & Ne \\
\hline Lahko sooblikujemo pouk. (92) & 29 & 14 & 14 & 35 \\
& $31,5 \%$ & $15,2 \%$ & $15,2 \%$ & 38,0 \\
\hline Učitelji upoštevajo naše mnenje. (90) & 29 & 29 & 19 & 13 \\
& $32,2 \%$ & $32,2 \%$ & $21,1 \%$ & $14,4 \%$ \\
\hline $\begin{array}{l}\text { Menim, da se pouk ne sme dogajati samo v razredu, ampak tudi } \\
\text { izven. (92) }\end{array}$ & $\begin{array}{c}77 \\
\text { (93,6\% }\end{array}$ & $5,4 \%$ & $4,3 \%$ & $6,5 \%$ \\
\hline
\end{tabular}


Preglednica 12: Sodelovanje v družbenem življenju

Table 12: Partizipation in social life

\begin{tabular}{|l|c|c|c|c|}
\hline & Ja & Prej ja & Prej ne & Ne \\
\hline Zanimam se, kaj se dogaja v moji občini. (92) & 20 & 12 & 19 & 41 \\
& $21,7 \%$ & $13,0 \%$ & $20,6 \%$ & $44,6 \%$ \\
\hline Zanimam se, kaj se dogaja v moji državi. (91) & 26 & 24 & 17 & 24 \\
& $28,6 \%$ & $26,4 \%$ & $18,7 \%$ & $26,4 \%$ \\
\hline Zanimam se, kaj se dogaja v Evropi. (92) & 31 & 15 & 21 & 25 \\
\hline Pri pouku se pogovarjamo o političnih dogajanjih. (92) & $33,7 \%$ & $16,3 \%$ & $22,8 \%$ & $27,1 \%$ \\
\hline
\end{tabular}

Tudi učenci v Radljah ob Dravi slabi poznajo šolski parlament, želijo pa več sodelovati na šoli, preko predstavnikov šole menijo, da nimajo dovolj teh možnosti. Pri pouku jih kar polovica meni, da ne morejo sodelovati. Učitelji upoštevajo stališče otrok, le ti pa podpirajo, da se pouk dogaja tudi izven razreda. V družbenem življenju se manj zanimajo za dogajanja v lastni občini, tudi za dogajanja v lastni državi se ne zanimajo preveč, nekoliko bolj za dogajanja v Evropi, o političnih dogodkih pa se skoraj ne pogovarjajo.

Zanimivo je, da so učenci iz vseh treh šol precej podobno odgovarjali na zastavljena vprašanja, čeprav so šole v različnih geografsko gledano območjih z različno zgodovino.

Sledi primerjava med šolami glede na posamezna vprašanja s ciljem, da zaznamo razlike in podobnosti med mnenji otrok tre vzroke za njih.

\section{PRIMERJAVA MED ŠOLAMI}

Graf 1: Možnost sodelovanja na šoli preko šolskega parlamenta

Graph 1: The posibilities for partizipation through the school parlament

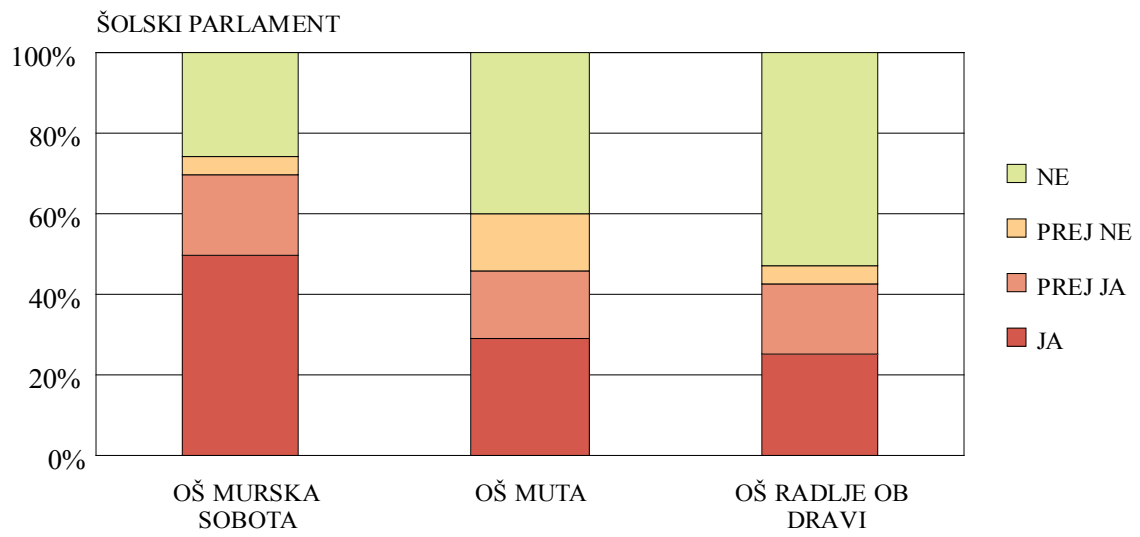


Šolski parlamenti se niso uveljavili v slovenskih šolah, otroci jih sicer poznajo, vendar smo ugotovili, da je zastopstvo preko parlamentov bolj vezano na različne dogodke na šolah, kjer sodelujejo predstavniki učencev in ne toliko na dejansko sodelovanje preko šolskega leta.

\section{Graf 2: Sodelovanje na šoli}

Graph 2: Partizipation in the school

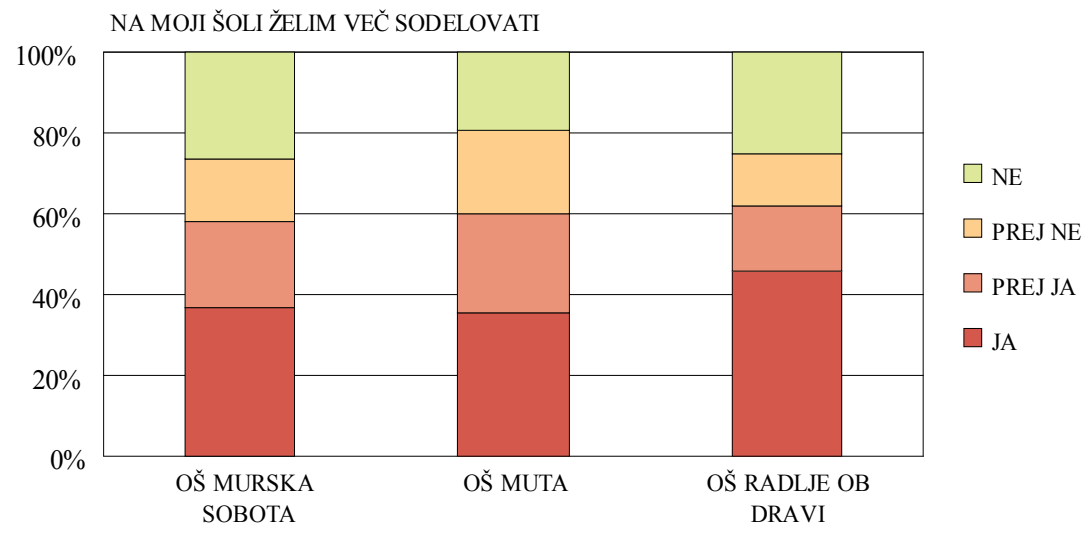

Več kot polovica otrok želi na šoli več sodelovati, kar je pohvalno s strani otrok. Škoda, da ne izkoristimo tega potenciala, saj je aktivno sodelovanje izredno pomemben motivacijski element v šoli. Le okoli 20 \% otrok ni izkazalo interesa po aktivnem sodelovanju, kar je glede na razlike med otroci popolnoma normalno.

Graf 3: Preko predstavnika šole lahko aktivno sodelujemo pri organizaciji življenja na šoli Graph 3: Through the studnet representative I can be active with organising school life

PREKO PREDSTAVNIKA ŠOLE LAHKO AKTIVNO SODELUJEMO PRI ORGANIZACIJI ŽIVLJENJA NA ŠOLI.

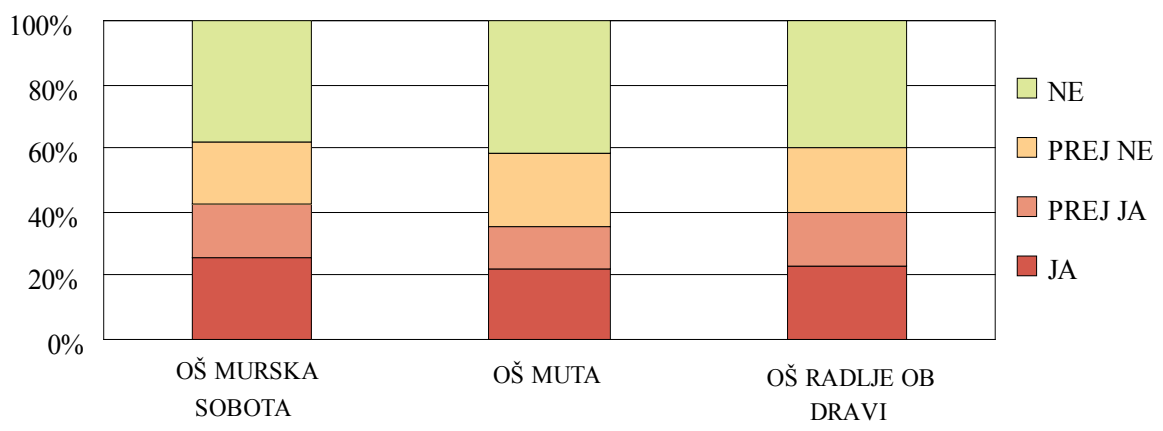


Čeprav otroci želijo aktivno sodelovati pri pouku in šoli, pa vendar teh možnosti ne vidijo preko predstavnika šole. Ker so tudi pri šolskem parlamentu izrazili podobno nemožnost, je potrebno razmisliti, kdo so predstavniki šole, kako ti delujejo, kako je organiziran sistem povezave z učenci. Vsekakor učenci ne ocenjujejo dobro možnosti sodelovanja preko predstavnikov.

Graf 4: Lahko sooblikujemo pouk

Graph 4: We can form together classlesens

LAHKO SOOBLIKUJEMO POUK

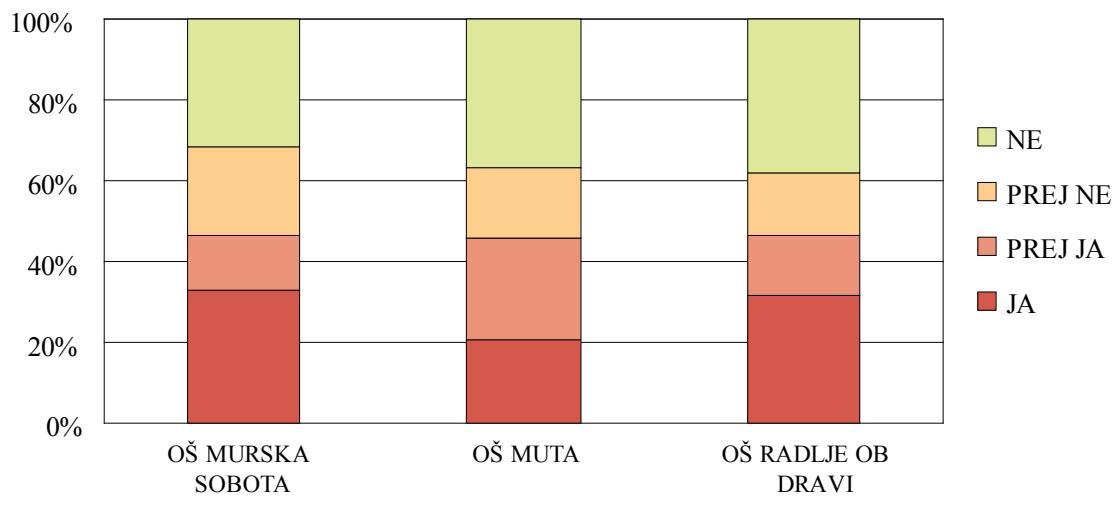

Graf 5: Učitelji upoštevajo naše mnenje

Graph 5: The teachers resprect the studnet oppinien

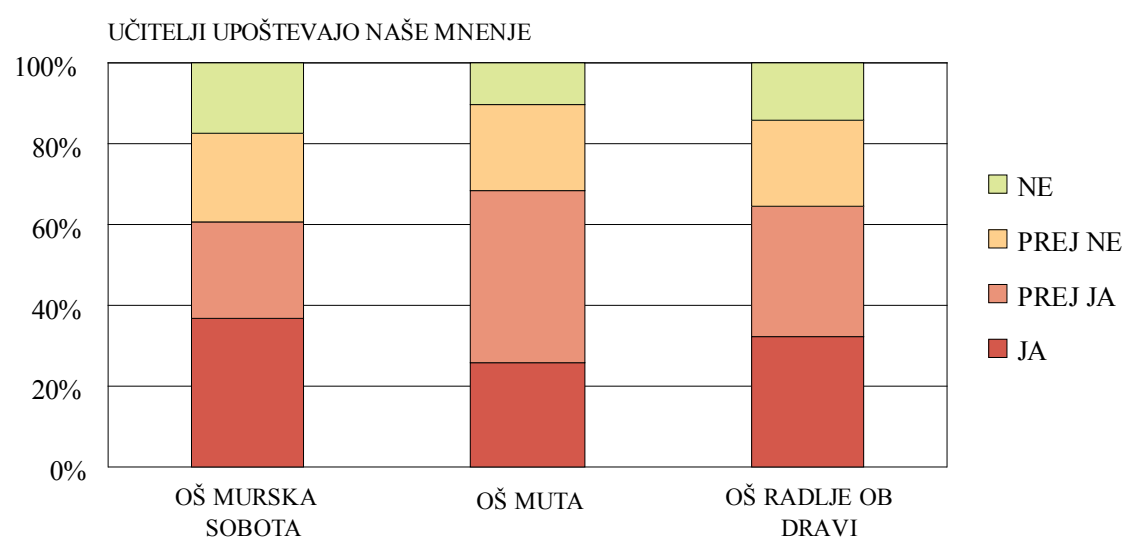

Glede sooblikovanja pouka so učenci OŠ Mute v najslabšem položaju, v OŠ Radlje ob Dravi in OŠ Murska Sobota pa približno enako ocenjujejo možnosti sooblikovanja pouka. 
Zagotovo bi bilo treba bolj aktivno vključiti otroke v vse možne načine za sooblikovanje pouka, saj lahko le ti mnogokrat prinesejo dobre zamisli, koristne za vse otroke.

Kljub slabšim možnostim sooblikovanja pouka pa otroci menijo, da učitelji upoštevajo njihovo mnenje, kar meni več kot polovica otrok v vseh treh OŠ. Učenci se čutijo veliko bolj odgovorne, če se njihova mnenja upoštevajo, zato je potrebno upoštevati mnenje otrok, kjer je to možno.

Graf 6: Menim, da se pouk ne sme dogajati samo v razredu, ampak tudi izven Graph 6: I think, the lessions schould not be only tought inside, but also outside

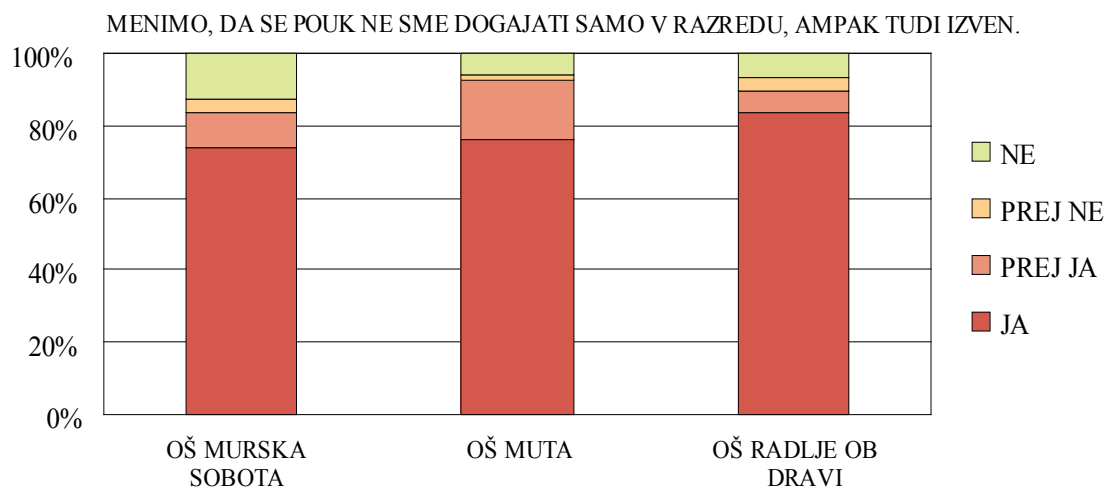

Graf 7: Zanimam se, kaj se dogaja v moji občini

Graph 7: I am curious what is happening in my municipality

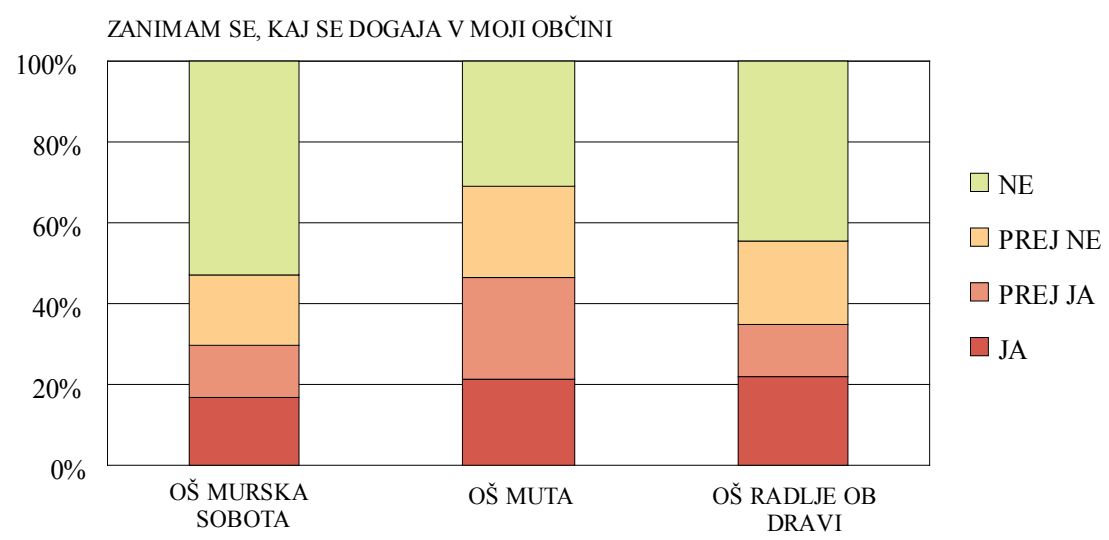

Najbolj enoten odgovor vseh učencev je bil glede tega, da bi se moral pouk odvijati tudi izven razreda. S tem se kaže želja učencev po fleksibilnem pouku. Osebno menim, da 
premalo izkoristimo to možnost, da se pouk dogaja izven razreda, ne samo v OŠ, temveč na vseh stopnjah šolanja.

Približno enak delež učencev, okoli 20\%, vseh treh OŠ meni, da jih zanima dogajanje v njihovi občini. Največji delež učencev, ki jih to dogajanje ne zanima, prihajajo iz OŠ Murska Sobota, sledi OŠ Radlje ob Dravi. Na OŠ Muta je največji delež tistih otrok, ki jih zanima takšno dogajanje. Nasploh se otroci manj zanimajo za dogajanja v občini.

Graf 8: Zanimam se, kaj se dogaja v moji državi

Graph 8: I am curius what is happening in my countries

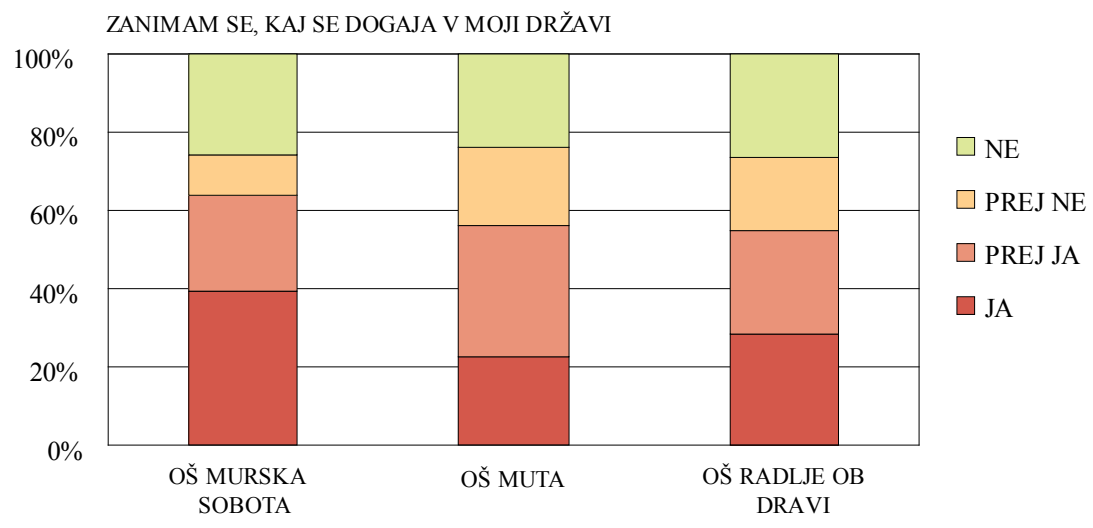

Največ otrok, ki se zanima, kaj se dogaja v njihovi državi, prihaja iz OŠ Murska Sobota, tem sledijo otroci iz preostalih dveh OŠ, ki imajo približno enako zastopana odgovora »ja« in

Graf 9: Zanimam se, kaj se dogaja v Evropi

Graph 9: I am curius what is happening in Europa

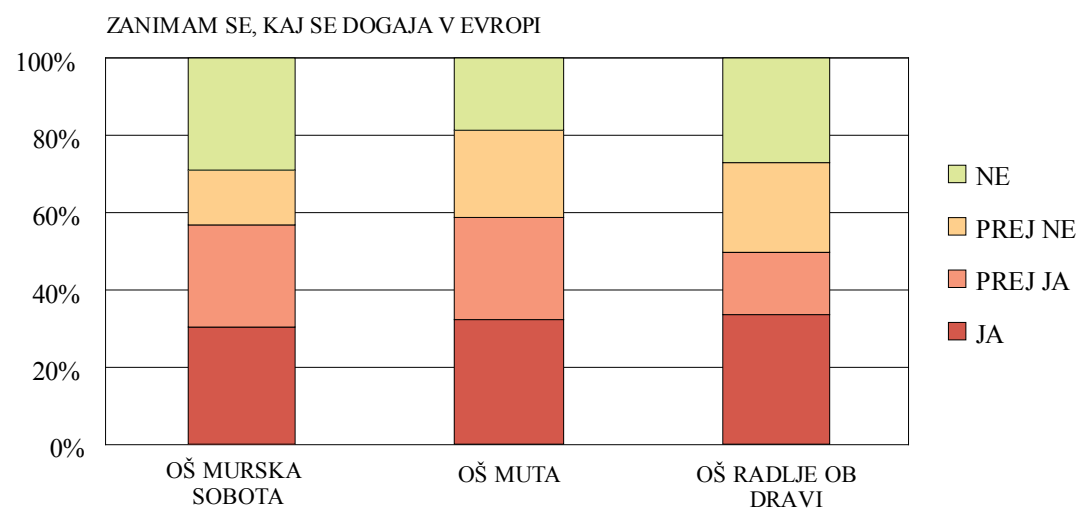


"prej ja«. Zanimanje za dogajanja v državi je večje kot zanimanje za dogajanje v lastni občini, kar je tudi posledica dejstva, se v šolah o lastnih občinah ne poučuje, oz. se redko omenja.

Tretjina otrok vseh treh OŠ zanima, kaj se dogaja v Evropi. Če bi združili odgovora »prej ne« in »ne«, bi iz grafa izstopala OŠ Radlje ob Dravi, kajti polovica odgovorov pripada tej možnosti. Največji delež otrok, ki se zanima za dogajanje v Evropi pripada OŠ Muta. Sicer pa je zanimanje za dogajanja v Evropi večje kot za dogajanja v lastni državi ali občini. Zagotovo $\mathrm{k}$ temu pripomorejo vsebine iz Regionalne geografije Evrope in druge, ki približajo otrokom dogajanja v Evropi.

Graf 10: Pri pouku se pogovarjamo o političnih dogajanjih

Graph 10: During the lessions we talk about the politics

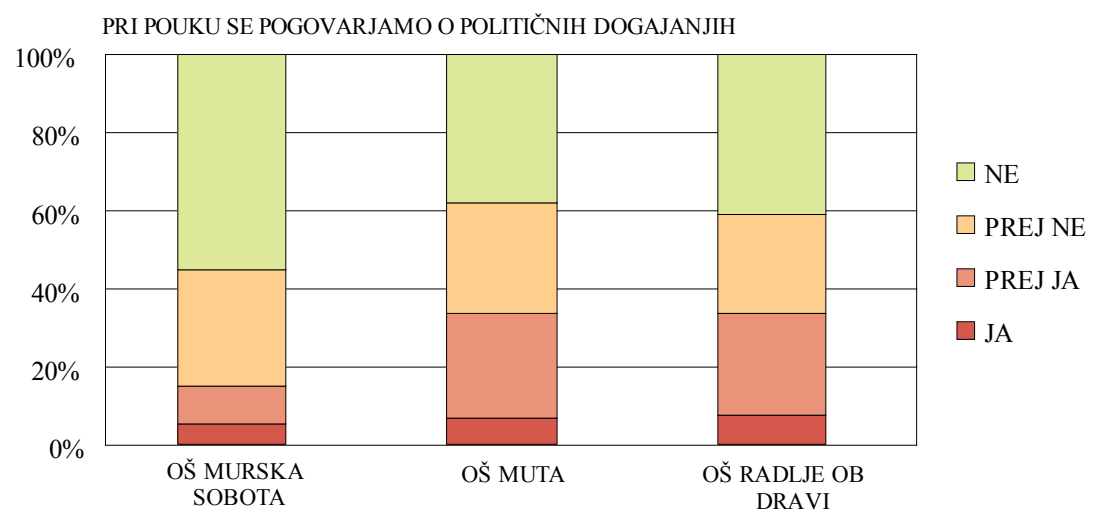

Politika in pogovor o političnih dogodkih sta na vseh treh šolah zelo slabo zastopana. Morda je pojem politika obarvan preveč odločevalsko, saj bi sicer bilo zelo koristno, da bi se otroci že v OŠ seznanili z dogajanji, ki so politično zasnovana in ki omogočajo vplivanja v javnem življenju. Osebno menim, da bi pojem politika morali razumeti širše, kot se razume sedaj, zlasti na šolah.

\section{AKTIVNOSTI ŠOL ZA VKLJUČEVANJE V JAVNO ŽIVLJENJE}

Z željo, da bi povečali aktivno sodelovanje šol v družbenem življenju smo v okviru projekta EUBIS organizirali po vseh treh šolah aktivnosti:

OŠ Radlje ob Dravi je sodelovala pri ureditvi učne poti Dobrava, ki poteka po občini Radlje ob Dravi. Učna pot Dobrava je tematsko geografska učna pot, pri opremi te poti pa je šola sodelovala še z Univerzo v Mariboru, Mednarodnim centrom za ekoremedaicje, občino Radlje ob Dravi, Turističnim in športnim društvom Dobrava ter z zainteresiranimi posamezniki. Učna pot je opisana v brošuri Vodna učna pot Dobrava, 2007. 
OŠ Murska Sobota je sodelovala pri pripravi in izdaji knjige Pojdimo k potoku, 2007. Knjiga je namenjena medpredmetni okoljski vzgoji in njeno izdajo je podprl Zavod za šolstvo, OE Maribor. V knjigi so zbrane naloge za terensko delo ob potoku in so tematsko vezane na vsa področja geografije (od fizične do družbene).

OŠ Muta je sodelovala pri izdaji plakata Mučka Bistrica in razvoj ob reki z ekoremediacijami. Vsebinsko plakat prikazuje načrtovan sonaravni razvoj ob reki Mučka Bistrica, ideje o razvoju so bile zbrane na delavnicah z občani (8. in 9. 9. 2006). Plakat je razstavljen na vseh uradnih mestih v občini, dobila so ga gospodinjstva.

\section{ZAKLJUČEK}

Anketni vprašalniki za učence $\mathrm{v}$ osnovnih šolah so pokazali, da si otroci želijo bolj aktivno sodelovanje $\mathrm{v}$ družbi, da želijo biti aktivni in da podpirajo učenje na prostem. Zato smo organizirali v treh izbranih šolah (OŠ Radlje ob Dravi, OŠ Murska Sobota in OŠ Muta) konkretne aktivnosti, kjer so učenci in učitelji sodelovali z občino (županom), društvi, z Univerzo v Mariboru ter predvsem, okrepilo se je sodelovanje znotraj šole. Učenci so aktivno pomagali tako v Radljah ob Dravi pri nastanku učne poti in sedaj so učenci skrbniki te učne poti, na šoli imajo tudi razstavo o učni poti. To je zelo pohvalno, saj živijo s to potjo.

V OŠ Murska Sobota so učenci izvajali naloge na terenu s področja različnih predmetov, le te smo nato vključili v priročnik Pojdimo k potoku. Učenci te šole se tudi sedaj pripravljajo na različne aktivne oblike sodelovanja tako pri novo nastajajoči Vodni učni poti Mokoš kot pravkar nastali Geografski učni poti Selo.

Naša ugotovitev je, da šole premorejo velik potencial, da želijo sodelovati v javnosti, da bi lahko bile bistveno bolj viden člen v družbi, ko so danes. Predvsem je pomembno, da si to najbolj želijo učenci, ki danes pogrešajo tak način učenja, zato bomo z dodatnimi dejavnostmi spodbujali povezave med šolami in drugi organizacijami s skupnim ciljem, biti aktivni členi v javnem življenju.

\section{Viri in literatura}

EUBIS, zloženka izdana ob predstavitvi projekta, Socrates, Education and Culture)

Vovk Korže, A., Jurač, V., 2007: Vodna učna pot Dobrava. Mednarodni center za ekoremediacije, Filozofska fakulteta Maribor.

Vovk Korže, A., Katalnić, D., Katalnić, E., 2007: Pojdimo k potoku. Mednarodni center za ekoremediacije, Filozofska fakulteta Maribor.

The Globe programme - Global Learning and Observations to Benefit the Environment

URL: http://www.globe.gov (citirano 1.6.2002)

http://www.rave-space.org/RaveSpace/HomePage.aspx (3. 1. 2008)

http://www.tutkiva.edu.hel.fi/yhteisto.htm (14.2. 2008)

http://ec.europa.eu/youreurope/nav/sl/citizens/citizenship/citizenship/index.html (3. 1.2008)

http://www.europarl.europa.eu/sides/getDoc.do?pubRef=-//EP//TEXT+TA+P6-TA-2006-

$0318+0+\mathrm{DOC}+\mathrm{XML}+\mathrm{V} 0 / / \mathrm{SL}(31.8 .2007)$ 


\section{SCHOOL CONTRIBUTION TO THE ECOLOGICAL DEVELOPMENT THE LOCAL COMUNITIES}

\section{Summary}

With the entry of Slovenia into the European Union, our state engaged itself to cooperate with other contries more tightly also on the area of education (Lisabon declaration). So the Slovenia also took part within EUBIS project with the full title »EU citizenship: The social participation for Europe starts in the primary schook. The main goal of this project is to increase the processes of participation in the school and society, what would help the pupils to become active and responsible citizens (EUBIS, the paper published at he presentation of project Socrates, Education and Culture). The Slovenia is within the project represented by University of Maribor, Faculty of Arts, as well by three invited primary schools: primary school Murska Sobota, primary school Muta and primary school Radlje ob Dravi. All three primary schools are connected within different happenings over the borders. OS Muta and Radlje ob Dravi are strongly connected to neighbouring Austria, because of the close distance and large tradition, while the OŠ Murska Sobota is strongly involved with the Prekmurje to the neighbouring Hungary. The school managment decided to involve in the project the pupils of the eighth and nineth school year (last two years of the primary school in Slovenia), which are aged between 13 and 15 years. Those pupils filled out the prepared questionnaires and so contributed to gathering of important data about the cooperation of pupils in the public life.

\section{The goals of the EUBIS project}

The projects contributes to the development of today's young people to become more responsible and more critical citizens, in the way, that they develop their ability of social participation and all necessary skills within this process. The main goal of the project in to increase the participation processes in the school and society, which at the end could contribute to the common mental growth of Europe.

\section{The subgoals of the project are:}

- To encourage young people, that they become more active inside the education process and in the society

- To improve the education development and education culturs in the sense of spreading the term »democracy«

- To enable the young people the participation in the school and society

- To make the participation in school more transparent, reflective and authenticate

- To develope the interactive methods and strategies between school and society

- To enable the teachers to manage the forms and ways of pupils' participation in the education process. 


\section{The main activities:}

- The analysis of curricula, existent materials, the examples of good practice

- The trial and evaluation on national and transparent level

- The widening and valorization of results on national and european level

- The development and execution of comenius courses.

\section{The results:}

- The modules for teachers' education

- The brochures, the Eubis plans with the results on CD

- The civil portfolio

- The leaflet the young people participation.

With analysis of questionnaires the clear response was obtained, that the cooperation of pupils in the society is not satisfactory, because between the life in the school and happening in the society still exist big differences. The opinions of the pupils in all three selected primary schools are very similar and only a small deviations could be found. Only a small percent of pupils is interested in what is happening in their community, contry and Europe. The interests for outside world and for the political happening are also not stimulated by the teachers. We believe that the teachers should bring up to pupils the interest in societial life, because we are all living in the time, when the happenings in Europe and in the world have very big influnce also to the happening in our country and near environs.

It was also ascertained, that the teachers only a little follow the actual events, because the school system in Slovenia at all times tends to fullfil the curriculum, which because of the time lack doesn't allow the introduction of present themes. Because of that we believe, that in schools the inclusion of pupils in the projects schould be offered, where they could develop their inerests for areas, which are not covered in the curricula. So the pupils interests to participate in the public life would be increased. Of course, in the process also the external cooperators should be incorporated. From the questionnaires is also evident, that the pupils are wishing to have a new possibility of active participation within the school and also out of it. 
Priloga: Vprašalnik za šole

\section{EUBIS \\ VPRAŠALNIK ZA VKLJUČENE ŠOLE V EVROPSKI PROJEKT}

Starost: let

1. Vključenost $v$ šolsko življenje

\begin{tabular}{|l|l|l|l|l|}
\hline $\begin{array}{l}\text { Ali imaš možnosti v tvoji šoli sodelovati na naslednjih } \\
\text { podroçih? }\end{array}$ & ja & $\begin{array}{c}\text { Prej } \\
\text { ja }\end{array}$ & $\begin{array}{c}\text { Prej } \\
\text { ne }\end{array}$ & ne \\
\hline Izbor učbenikov & & & & \\
\hline Oblikovanje izgleda razreda & & & & \\
\hline Oblikovanje izgleda šolskega dvorišča & & & & \\
\hline Dogajanje v razredu & & & & \\
\hline Projektni dnevi/tedni & & & & \\
\hline Šolski parlament & & & & \\
\hline Disciplina v šoli & & & & \\
\hline Prireditve na šoli & & & & \\
\hline Urniki & & & & \\
\hline Razdelitev finančnih sredstev & & & & \\
\hline Kaj meniš h naslednjim izjavam? & & & & \\
\hline $\begin{array}{l}\text { Ne želim bolj aktivno sodelovati v šoli, } \\
\text { tako se počutim vredu. }\end{array}$ & & & & \\
\hline Naši učitelji samo določijo, kaj se dogaja v šoli. & & & & \\
\hline Na moji šoli želim več sodelovati. & & & \\
\hline $\begin{array}{l}\text { Preko predstavnika šole lahko aktivno sodelujem pri } \\
\text { organizaciji življenja na šoli. }\end{array}$ & & & \\
\hline
\end{tabular}

Če želiš, lahko zadnje 4 izjave komentiraš. 


\section{Sodelovanje pri pouku}

\begin{tabular}{|l|l|l|l|l|}
\hline & ja & $\begin{array}{c}\text { Prej } \\
\text { ja }\end{array}$ & $\begin{array}{c}\text { Prej } \\
\text { ne }\end{array}$ & ne \\
\hline Lahko sooblikujemo pouk. & & & & \\
\hline Učitelji nam jasno predstavijo njihove zahteve. & & & & \\
\hline Učitelji nam pomagajo pri učnih težavah. & & & & \\
\hline Učitelji nas pogosto vprašajo o našem mnenju. & & & \\
\hline Učitelji upoštevajo naše mnenje. & & & & \\
\hline Pogosto sodelujemo pri projektih. & & & & \\
\hline Imamo dovolj časa, da predstavljamo rezultate projekta. & & & & \\
\hline Pogosto delamo skupaj v skupinah. & & & & \\
\hline Pri pouku se poslušamo. & & & & \\
\hline $\begin{array}{l}\text { Menim, da se pouk ne sme dogajati samo v razredu, } \\
\text { amapak tudi izven. }\end{array}$ & & & \\
\hline Pri pouku sodelujejo strokovnjaki od zunaj. & & & \\
\hline
\end{tabular}

\section{Sodelovanje v družbenem življenju}

\begin{tabular}{|l|l|l|l|l|}
\hline & ja & $\begin{array}{c}\text { Prej } \\
\text { ja }\end{array}$ & $\begin{array}{c}\text { Prej } \\
\text { ne }\end{array}$ & Ne \\
\hline V šoli delamo skupaj z zunanjimi sodelavci. & & & & \\
\hline Zanimam se, kaj se dogaja v moji občini. & & & & \\
\hline Zanimam se, kaj se dogaja v moji državi. & & & & \\
\hline Zanimam se, kaj se dogaja v Evropi. & & & & \\
\hline Vsak dan berem aktualne članke v časopisu. & & & & \\
\hline Gledam poročila na televiziji. & & & & \\
\hline Pogovarjam se s prijatleji o političnih dogajanjih. & & & & \\
\hline Pri pouku se pogovarjamo o političnih dogajanjih. & & & & \\
\hline Sem član organizacije, društva. & & & & \\
\hline
\end{tabular}

